\title{
Sex differences in dietary intake in British Army recruits undergoing phase one training
}

\author{
Shaun Chapman ${ }^{1,2^{*}} \mathbb{D}$, Justin Roberts ${ }^{2}$, Lee Smith², Alex Rawcliffe ${ }^{1}$ and Rachel Izard ${ }^{1}$
}

\begin{abstract}
Background: British Army Phase One training exposes men and women to challenging distances of $13.5 \mathrm{~km} \cdot \mathrm{d}^{-1} \mathrm{vs}$. $11.8 \mathrm{~km} \cdot \mathrm{d}^{-1}$ and energy expenditures of $\sim 4000 \mathrm{kcal} \cdot \mathrm{d}^{-1}$ and $\sim 3000 \mathrm{kcal} \cdot \mathrm{d}^{-1}$, respectively. As such, it is essential that adequate nutrition is provided to support training demands. However, to date, there is a paucity of data on habitual dietary intake of British Army recruits. The aims of this study were to: (i) compare habitual dietary intake in British Army recruits undergoing Phase One training to Military Dietary Reference Values (MDRVs), and (ii) establish if there was a relative sex difference in dietary intake between men and women.

Method: Researcher led weighed food records and food diaries were used to assess dietary intake in twenty-eight women (age $21.4 \pm 3.0 \mathrm{yrs}$., height: $163.7 \pm 5.0 \mathrm{~cm}$, body mass $65.0 \pm 6.7 \mathrm{~kg}$ ), and seventeen men (age $20.4 \pm 2.3 \mathrm{yrs}$., height: $178.0 \pm 7.9 \mathrm{~cm}$, body mass $74.6 \pm 8.1 \mathrm{~kg}$ ) at the Army Training Centre, Pirbright for 8-days in week ten of training. Macro and micronutrient content were estimated using dietary analysis software (Nutritics, Dublin) and assessed via an independent sample t-test to establish if there was a sex difference in daily energy, macro or micronutrient intakes.
\end{abstract}

Results: Estimated daily energy intake was less than the MDRV for both men and women, with men consuming a greater amount of energy compared with women ( $2846 \pm 573$ vs. $\left.2207 \pm 585 \mathrm{kcal} \cdot d a y^{-1}, p<0.001\right)$. Both sexes under consumed carbohydrate $(\mathrm{CHO})$ when data was expressed relative to body mass with men consuming a greater amount than women ( $4.8 \pm 1.3$ vs. $\left.3.8 \pm 1.4 \mathrm{~g} \mathrm{~kg}^{-1} \cdot \mathrm{day}^{-1}, p=0.025, \mathrm{ES}=0.74\right)$. Both sexes also failed to meet MDRVs for protein intake with men consuming more than women $\left(1.5 \pm 0.3 \mathrm{vs} .1 .3 \pm 0.3 \mathrm{~g}^{\mathrm{kg}}{ }^{-1} \cdot \mathrm{day}^{-1}, p>0.030, \mathrm{ES}=0.67\right)$. There were no differences in dietary fat intake between men and women $\left(1.5 \pm 0.2 \mathrm{vs} .1 .5 \pm 0.5 \mathrm{~g} \cdot \mathrm{kg}^{-1} \cdot\right.$ day $^{-1}, p=0.483$, $\mathrm{ES}=0.00$ ).

Conclusions: Daily El in men and women in Phase One training does not meet MDRVs. Interventions to increase macronutrient intakes should be considered along with research investigating the potential benefits for increasing different macronutrient intakes on training adaptations.

Keywords: Dietary intake, Military, Sex differences, Exercise training

\footnotetext{
* Correspondence: shaun.chapman101@mod.gov.uk

${ }^{1} \mathrm{HQ}$ Army Recruiting and Initial Training Command, UK Ministry of Defence,

Upavon, UK

${ }^{2}$ Cambridge Centre for Sport and Exercise Sciences, School of Psychology

and Sport Science, Anglia Ruskin University, East Road, Cambridge CB1 1PT,

England
}

(C) The Author(s). 2019 Open Access This article is distributed under the terms of the Creative Commons Attribution 4.0 International License (http://creativecommons.org/licenses/by/4.0/), which permits unrestricted use, distribution, and

reproduction in any medium, provided you give appropriate credit to the original author(s) and the source, provide a link to the Creative Commons license, and indicate if changes were made. The Creative Commons Public Domain Dedication waiver (http://creativecommons.org/publicdomain/zero/1.0/) applies to the data made available in this article, unless otherwise stated. 


\section{Introduction}

British Army standard entry Phase One training is a 14week training syllabus that includes physical training, field exercises and training on a variety of military-specific skills including load carriage, marching, military drill and weapon and equipment handling [1]. It is characterised by high rates of injury and medical discharge (MD) [1-3]. In Phase One training the overall rate of injury is 0.07 people injured per 100 person-days and that the overall MD rate is 0.02 people injured per 100 person-days [2]. Recruits are exposed to high daily training loads and energy expenditures (EE) which, without adequate nutrient provision, may contribute to a reduction in mood state [4] compromised physical performance, increased musculoskeletal injury (MSKi) risk $[5,6]$ and medical discharge (MD). Estimated daily EE and training distance covered in Phase One training in men has been reported to be $\sim 4000 \mathrm{kcal}$ and $13.5 \pm$ $6.6 \mathrm{~km}$ and in women was $\sim 3000 \mathrm{kcal}$ and $11.8 \pm 4.9 \mathrm{~km}$ for men and women, respectively [1]. Women are at greater risk of MSKi during British Army Phase One training and this is supported by evidence that demonstrates women to be 2-3 times at greater risk of injury [2]. The increased risk is not due to sex differences per se but likely due to lower aerobic fitness levels in women, resulting in higher internal load [1, 2, 7]. Therefore, women may require additional dietary support, such as energy and/or protein intake, to facilitate skeletal muscle repair and support the higher training load compared to men [1]. To date, however, there is no suggestion that separate protein intakes should be recommended for men and women. To maintain muscle mass, strength and performance during periods of substantial metabolic demands and concomitant negative energy balance it is recommended a protein intake of at least $1.5 \mathrm{~g} \cdot \mathrm{kg}^{-1} \cdot \mathrm{d}^{-1}$ is consumed [8].

In response to a similar training load women have been shown to have greater fatigue resistance and maintenance of muscle function to men [9]. Following a loaded march during British Army training, men had a greater loss in maximal voluntary contractions (MVC) of the knee extensors than women $(12 \pm 9 \%$ vs. $9 \pm 13 \%, p=0.03)$. The authors suggested that this may have been due to woman possessing a greater proportion of type 1 muscle fibres in the knee extensor muscles. Nevertheless, the MVC and vertical jump height of men following load carriage was still higher than the pre-exercise values for the women and therefore, muscle performance rather than fatigability per se, may contribute to the sex difference in injury incidence $[2,9]$. The higher baseline values in the men perhaps allows for greater degradation [9]. Therefore, the lower baseline values in the women may indicate a requirement for nutritional interventions to enhance skeletal muscle recovery. Women may also require other dietary interventions to support training, particularly as recent evidence has shown women to under consume various micronutrients such as iron and calcium, during military training by 77 and $75 \%$, respectively [10].

Dietary intake should match energy expenditure to maintain health and performance and evidence to support this has been extensively reviewed [11-13]. Specifically, an inadequate energy intake (EI) is harmful to performance [4], bone health $[5,14,15]$, immune function [16], cognition [17], mood [4] and MSKi risk [5]. It has therefore been recommended to consume $3100-4100 \mathrm{kcal} \cdot \mathrm{d}^{-1}$, specific to Phase one training [18]. Moreover, a negative energy balance of $>500 \mathrm{kcal} \cdot \mathrm{d}^{-1}$ is detrimental to health in the longer term. It has been shown that an energy deficit of this magnitude suppresses the hormone milieu, reduces thyroid function and reduces exercise performance by $9.8 \%$ [19]. Reduced thyroid function is of particular concern in military populations due to the suppression on bone formation markers and subsequent risk of a stress fracture [20]. In a crossover study, endurance trained runners undergoing an intense 11-day training programme whilst habitually consuming a diet lower in $\mathrm{CHO}$ (5.4 $\mathrm{g} \cdot \mathrm{kg}^{-1} \cdot \mathrm{d}^{-1}$ ) experienced a greater deterioration in global mood scores, than when consuming a diet with a higher CHO content $\left(8.5 \mathrm{~g} \cdot \mathrm{kg}^{-1} \cdot \mathrm{d}^{-1}\right)$ [4]. In military populations it is generally found that soldiers fail to meet recommended energy and nutrient intakes [10, 21-27]. McAdam et al. (2018) found that recruits undergoing Basic Training in the United States (U.S.) experienced a $595 \pm$ $896 \mathrm{kcal} \cdot \mathrm{d}^{-1}$ deficit and $70 \%$ of recruits consumed less than the lower limit $\left(6 \mathrm{~g} \cdot \mathrm{kg}^{-1} \cdot \mathrm{d}^{-1}\right)$ for recommended carbohydrate intake (CHO). Given the large standard deviation for energy intake $\left(896 \mathrm{kcal} \cdot \mathrm{d}^{-1}\right)$ some recruits would have been in a larger energy deficit across the training phase. It is possible that this deficit was underestimated due to the use of an accelerometer to quantify EE. Energy expenditure was estimated via an Actigraph wGT3X monitor using the Sasaki equation which has been shown to have a mean bias of -0.23 compared to indirect calorimetry [28]. It is also possible that EI was also underestimated due to an acute food diary collection period being used for analysis [29]. In the United Kingdom (UK), the Scientific Advisory Committee on Nutrition (SACN) have developed Military Dietary Reference Values (MDRVs) for British Army recruits [18], but no study has yet quantified dietary intake to establish if these are habitually met.

The aim of this study was therefore to quantify energy, macro and micronutrient intake of British Army recruits to determine if these were adequate compared to MDRVs and Recommended Daily Allowances (RDA). A secondary aim was to compare dietary intake between sexes to establish if future dietary interventions during training needed to be sex specific. Based on other studies in military populations, we hypothesized that men and women would not meet MDRVs for energy intake and that women would be 
at greater risk of nutrient deficiency compared to men due to a lower energy intake. The findings of this investigation will provide novel data into the nutritional intake of British Army recruits in Phase One training. This data may be used to inform future interventions aimed at improving nutrient intake in this population during British Army training.

\section{Materials/ methods}

\section{Ethical approval}

This study was approved by the U.K. Ministry of Defence Research Ethics Committee (MODREC). For inclusion, recruits at the Army Training Centre Pirbright (ATC(P)), Surrey, UK in week ten of training, were invited to take part. Interested participants received verbal explanation of the study from the research team and provided written informed consent. Twenty-eight women (mean \pm SD: age $21.4 \pm 3.0$ yrs., height: $163.7 \pm 5.0 \mathrm{~cm}$, body mass $65.0 \pm 6.7$ $\mathrm{kg}$, body mass index: $24.2 \pm 2.6 \mathrm{~kg} \cdot \mathrm{m}^{2}$ ) and seventeen men (mean \pm SD: age $20.4 \pm 2.3$ yrs., height: $178.0 \pm 7.9 \mathrm{~cm}$, body mass $74.6 \pm 8.1 \mathrm{~kg}$, body mass index: $22.5 \pm 1.7$ $\mathrm{kg} \cdot \mathrm{m}^{2}$ ) volunteered for this study, which was conducted in accordance with the declaration of Helsinki.

\section{Study design}

This was an observational cross-sectional study over an 8-day period. Sample size was based on a priori power analysis using G*power (v3.1.9.2, Dusseldorf) based on previously collected energy intake data in the literature [26]. It was determined that 24 participants $(12$ men and 12 women) were required to replicate the highest significant effect size of 1.05 for a between-sex difference in energy intake using $\alpha=0.05, \beta=0.80$. Participant demographics were collected on day one and diet analysis was collected on each day (days 1 to 8 ).

\section{Physical characteristics}

Height $(\mathrm{cm})$ and body mass $(\mathrm{kg})$ were recorded with recruits wearing Army uniform except for boots using a seca 213 mobile stadiometer and pre-calibrated seca flat scales (Hamburg, Germany).

\section{Diet logs}

Dietary intake was recorded using researcher-led food weighing at breakfast, lunch and dinner in the training centre dining facility. On arrival, participants chose their food and each portion was weighed using pre-calibrated food scales (Salter, 1066 BKDR15, Kent, UK). After each meal, participants were instructed to leave food discards so that these could also be weighed and subtracted from the original weight; to give the actual food portion consumed for that meal [30]. To capture dietary intake between meals and off-camp, participants completed food diaries following guided instructions and estimated the portion size using practical measures ( 1 cup, 2 handfuls, 1 palm size etc.) [29] and kept any snack or ration discards in discard bags to cross examine against food diaries. Participants were briefed on how to accurately complete a food diary and these were then checked by a member of the research team each day to clarify any unclear information.

\section{Nutritics analysis}

Food records were entered into nutritional analysis software (Nutritics, Dublin, Ireland) for the generation of mean daily energy, macronutrient and micronutrient intakes using the UK Scientific Advisory Committee on Nutrition $(\mathrm{SACN})$ database. The recipes of foods which did not already exist in the database (i.e. ration pack foods) were manually entered using the recipe or nutritional content information provided by the caterer. All data was inputted by the same researcher to reduce data processing variability [31].

\section{Data presentation and statistical analysis}

Physical characteristics and mean nutrient intakes were compared between sexes using an independent samples t-test. Prior to this, dietary intake data was tested for normality using a Shapiro-Wilks test (IBM SPSS v24). Where data showed a significant deviation from a normal distribution, a non-parametric equivalent (Mann Whitney U test) was used. Cohen's d effects (small $=0.2$, medium $=0.5$, large $=0.8$ ) were calculated for differences in nutrient intakes between men and women. Following an appropriate Bonferroni adjustment, an alpha level of $p<0.001$ was set.

\section{Results}

\section{Physical characteristics}

There was a statistically significant difference between sexes in stature (t $[22]=6.521, p=<0.001)$ and body mass ( $\mathrm{t}[32]=3.920, p=<0.001)$ but not age $(\mathrm{Z}=-$ $1.126, p=.260)$ or BMI (t [32] $=-1.224, p=0.228)$.

\section{Energy intake}

There was a statistically significant difference between sexes with men consuming more than women ( $\mathrm{t}$ [32]= 3.508, $p=0.001$, ES =1.10). Both men and women consumed less than the MDRVs, with men consuming 69\% and women consuming $72 \%$ of the recommended energy intake (Table 2). When data was expressed as relative to body there was no differences in energy intake between sexes $(\mathrm{t}[32]=1.396, p=0.170, \mathrm{ES}=0.46)($ Table 2$)$.

\section{Macronutrient intake}

Compared to the MDRVs, men and women under consumed $\mathrm{CHO}$ and protein with men consuming a greater absolute total daily amount of $\mathrm{CHO}$ than women $(\mathrm{Z}=$ - 
3.708, $p<0.001, \mathrm{ES}=1.27$ ). Men also consumed a greater total daily amount of protein than women $(\mathrm{Z}=-3.708, \mathrm{p}<$ 0.001 , ES $=1.28$ ). Total fat intake was not different between sexes $\mathrm{t}[32]=1.113, p=0.272, \mathrm{ES}=0.37$ ) but under consumed by men. Men consumed a greater amount of fibre than women ( $\mathrm{t}[32]=2.422, p=0.020, \mathrm{ES}=1.16)$ (Table 1). When data was expressed relative to body mass there was no difference between sexes for $\mathrm{CHO}$ ( $\mathrm{t}[32]=2.333, p=$ 0.025 , ES $=0.74$ ), protein ( $\mathrm{t}[32]=2.241, p=0.030, \mathrm{ES}=$ $0.67)$, fat $(\mathrm{t}[32]=-0.708, p=0.483, \mathrm{ES}=0.00)$ or fibre intake ( $\mathrm{t}[32]=0.840, p=0.406, \mathrm{ES}=0.00)$ (Table 2).

\section{Micronutrient intake}

When compared to men, women consumed less calcium $(\mathrm{t}[32]=3.645, p=0.001, \mathrm{ES}=1.06)$,iron $(\mathrm{t}[32]=4.262, p<$ $0.001,1.18$ ), sodium ( $[32]=2.700, p=0.010, \mathrm{ES}=0.77$ ), vitamin $\mathrm{B}_{6}(\mathrm{Z}=-3.123, p=0.002$, $\mathrm{ES}=0.91)$, vitamin $\mathrm{B}_{12}$ $(\mathrm{Z}=-3.477, p=0.001, \mathrm{ES}=1.11)$, potassium $(\mathrm{Z}=-2.537$, $p=0.011, \mathrm{ES}=0.86)$, niacin $(\mathrm{Z}=-4.062, p<0.001, \mathrm{ES}=$
1.42), iodine $(Z=-2.733, p=0.006$, $E S=0.91)$, thiamine $(\mathrm{Z}=-2.355, p=0.010)$, riboflavin $(\mathrm{Z}=-3.576, p<0.001$, $\mathrm{ES}=0.97)$, phosphorus $(\mathrm{Z}=-2.976, p=0.003, \mathrm{ES}=0.97)$ and folate $(Z=-3.391, p=0.001, E S=1.17)$. Men and women consumed less than the RDA for copper, magnesium and vitamin $\mathrm{D}$ with women consuming significantly less magnesium $(\mathrm{Z}=-2.464, p=0.014, \mathrm{ES}=0.84)$ and vita$\min \mathrm{D}(\mathrm{Z}=-2.257, p=0.024, \mathrm{ES}=1.00)$ but not copper $(\mathrm{t}$ $[32]=1.035, p=0.306, \mathrm{ES}=0.47)$. Women consumed an inadequate amount of vitamin A when compared to the RDA and this was significantly less than men $(\mathrm{Z}=-2.562$, $p=0.010, \mathrm{ES}=0.84$ ). Both men and women consumed adequate amounts of vitamin $C$ when compared to the RDA with no differences between sexes $(Z=-1.049, p=0.294$, $\mathrm{ES}=0.45)$. When micronutrient data was expressed relative to body mass there was no difference for iron ( $\mathrm{t}[32]=$ $2.468, p=0.18, \mathrm{ES}=0.75)$, calcium $(\mathrm{t}[32]=2.28, p=0.027$, $\mathrm{ES}=0.71)$, magnesium $(\mathrm{t}[32]=1.513, p=0.138, \mathrm{ES}=0.46)$, vitamin A (t [32] $=1.808, p=0.078, \mathrm{ES}=0.58)$, vitamin $\mathrm{C}(\mathrm{t}$

Table 1 Absolute nutrient intake for participants compared to MDRVs and RDA

\begin{tabular}{|c|c|c|c|c|c|}
\hline Nutrient & All & Men & MDRV & Women & MDRV \\
\hline Energy $\left(k^{\prime} a l \cdot\right.$ day $\left.^{-1}\right)$ & $2439 \pm 653$ & $2846 \pm 573^{*}$ & 4100.0 & $2207 \pm 585^{*}$ & 3100.0 \\
\hline $\mathrm{CHO}\left(\mathrm{g} \cdot \mathrm{day}^{-1}\right)$ & $283 \pm 98$ & $352 \pm 92^{*}$ & $513-615$ & $243 \pm 79^{*}$ & $388-465$ \\
\hline PRO (g.day ${ }^{-1}$ ) & $94 \pm 27$ & $114 \pm 29$ & $123-154$ & $83 \pm 18$ & $93-116$ \\
\hline Fat (g.day ${ }^{-1}$ ) & $103 \pm 25$ & $109 \pm 21$ & $128-159$ & $100 \pm 27$ & $96-121$ \\
\hline Fibre $\left(g \cdot\right.$ day $^{-1}$ ) & $20 \pm 6$ & $23 \pm 5$ & 30 & $18 \pm 1$ & 30 \\
\hline Calcium $\left(\mathrm{mg} \cdot \mathrm{d}^{-1}\right)$ & $837.0 \pm 383.0$ & $1078.0 \pm 418.0^{*}$ & 700.0 & $699.0 \pm 287.0^{*}$ & 700.0 \\
\hline Copper $\left(\mathrm{mg} \cdot \mathrm{d}^{-1}\right)$ & $0.9 \pm 0.3$ & $1.0 \pm 0.0$ & 1.2 & $0.9 \pm 0.3$ & 1.2 \\
\hline Folate $\left(\mu \mathrm{g} \cdot \mathrm{d}^{-1}\right)$ & $173.0 \pm 84.0$ & $231.0 \pm 95.0^{*}$ & 200.0 & $140.0 \pm 55.0^{*}$ & 200.0 \\
\hline lodine $\left(\mu \cdot d^{-1}\right)$ & $99.0 \pm 64.0$ & $135.0 \pm 79.0$ & 140.0 & $77.0 \pm 44.0$ & 140.0 \\
\hline Iron $\left(\mathrm{mg} \cdot \mathrm{d}^{-1}\right)$ & $8.7 \pm 3.0$ & $10.0 \pm 3.0^{*}$ & 8.7 & $7.0 \pm 2.0^{*}$ & 14.8 \\
\hline Magnesium $\left(\mathrm{mg} \cdot \mathrm{d}^{-1}\right)$ & $198.0 \pm 77.0$ & $239.0 \pm 94.0$ & 300.0 & $174.0 \pm 55.0$ & 270.0 \\
\hline $\operatorname{Niacin}\left(\mathrm{mg} \cdot \mathrm{d}^{-1}\right)$ & $14.8 \pm 6.3$ & $19.9 \pm 7.3^{*}$ & 16.5 & $12.0 \pm 3.0^{*}$ & 13.2 \\
\hline Phosphorus (mg.d ${ }^{-1}$ ) & $997.0 \pm 382.0$ & $1227.0 \pm 461.0$ & 550.0 & $865.0 \pm 254.0$ & 550.0 \\
\hline Potassium $\left(\mathrm{mg} \cdot \mathrm{d}^{-1}\right)$ & $2386.0 \pm 877.0$ & $2859.0 \pm 1051.0$ & 3500.0 & $2115.0 \pm 634.0$ & 3500.0 \\
\hline Riboflavin $\left(\mathrm{mg} \cdot \mathrm{d}^{-1}\right)$ & $1.1 \pm 0.7$ & $1.6 \pm 0.8^{*}$ & 1.3 & $0.8 \pm 0.4^{*}$ & 1.1 \\
\hline Selenium $\left(\mu \mathrm{g} \cdot \mathrm{d}^{-1}\right)$ & $39.0 \pm 21.0$ & $57.0 \pm 25.0$ & 75.0 & $29.0 \pm 11.0$ & 60.0 \\
\hline Sodium $\left(g \cdot d^{-1}\right)$ & $2.7 \pm 0.7$ & 3.0. \pm 0.6 & 2.4 & $2.5 \pm 0.7$ & 2.4 \\
\hline Thiamin $\left(\mathrm{mg} \cdot \mathrm{d}^{-1}\right)$ & $1.3 \pm 0.5$ & $1.5 \pm 0.5$ & 1.0 & $1.1 \pm 0.3$ & 0.8 \\
\hline Vitamin $A\left(\mu g \cdot d^{-1}\right)$ & $634.0 \pm 410.0$ & $840.0 \pm 388.0$ & 700.0 & $516.0 \pm 380.0$ & 600.0 \\
\hline Vitamin $B_{12}\left(\mu \mathrm{g} \cdot \mathrm{d}^{-1}\right)$ & $4.3 \pm 2.6$ & $6.0 \pm 3.2^{*}$ & 1.5 & $3.3 \pm 1.3^{*}$ & 1.5 \\
\hline Vitamin $B_{6}\left(\mathrm{mg} \cdot \mathrm{d}^{-1}\right)$ & $1.5 \pm 0.9$ & $2.0 \pm 1.2$ & 1.4 & $1.2 \pm 0.3$ & 1.2 \\
\hline Vitamin C $\left(\mathrm{mg} \cdot \mathrm{d}^{-1}\right)$ & $55.0 \pm 38.0$ & $67.0 \pm 49.0$ & 40.0 & $49.0 \pm 29.0$ & 40.0 \\
\hline Vitamin D $\left(\mu \mathrm{g} \cdot \mathrm{d}^{-1}\right)$ & $2.0 \pm 1.0$ & $2.0 \pm 1.0$ & 10.0 & $1.0 \pm 1.0$ & 10.0 \\
\hline $\operatorname{Zinc}\left(\mathrm{mg} \cdot \mathrm{d}^{-1}\right)$ & $7.1 \pm 2.5$ & $8.0 \pm 3.0$ & 9.5 & $6.0 \pm 1.0$ & 7.0 \\
\hline
\end{tabular}

Energy, macronutrient and micronutrient intake of all participants and with data grouped according sex to establish differences in intakes. Intakes for each sex were then compared to recommendations. The recommended MDRV for CHO, protein and fat towards total energy intake is $50-60 \%, 12-15 \%$ and $28-35 \%$, respectively. These values were used to calculate the absolute amount of $\mathrm{CHO}$, protein and fat needed to achieve the required energy intake in men (4100

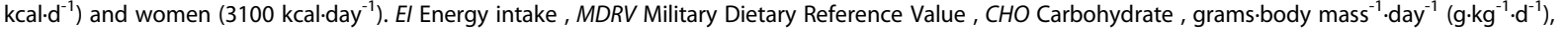
milligrams $\cdot$ day $^{-1}\left(\mathrm{mg}^{-1} \mathrm{~d}^{-1}\right)$ and micrograms $\cdot \mathrm{day}^{-1}\left(\mu \mathrm{g} \cdot \mathrm{d}^{-1}\right)$. *indicates a statistically significant differecnce between sexes 
Table 2 Relative daily nutrient intakes for participants compared to MDRVs/RDA and Sport Nutrition guidelines

\begin{tabular}{|c|c|c|c|c|c|}
\hline Nutrient & All & Men & MDRV & Women & MDRV \\
\hline Energy $\left(\mathrm{kcal} \cdot \mathrm{kg}^{-1} \cdot \mathrm{d}^{-1}\right)$ & $35.7 \pm 9.5$ & $38.3 \pm 7.3$ & 55.0 & $34.2 \pm 10.3$ & 48.0 \\
\hline $\mathrm{CHO}\left(\mathrm{kcal} \cdot \mathrm{kg}^{-1} \cdot \mathrm{d}^{-1}\right)$ & $4.1 \pm 1.4$ & $4.8 \pm 1.3$ & $6.0-8.0$ & $3.8 \pm 1.4$ & $6.0-7.0$ \\
\hline PRO $\left(\mathrm{kcal} \cdot \mathrm{kg}^{-1} \cdot \mathrm{d}^{-1}\right)$ & $1.4 \pm 0.4$ & $1.5 \pm 0.3$ & $1.6-2.0$ & $1.3 \pm 0.3$ & $1.4-1.8$ \\
\hline Fat $\left(\mathrm{kcal} \cdot \mathrm{kg}^{-1} \cdot \mathrm{d}^{-1}\right)$ & $1.5 \pm 0.4$ & $1.5 \pm 0.2$ & $1.7-2.1$ & $1.5 \pm 0.5$ & $1.5-1.9$ \\
\hline Fibre $\left(\mathrm{kcal} \cdot \mathrm{kg}^{-1} \cdot \mathrm{d}^{-1}\right)$ & $0.3 \pm 0.1$ & $0.3 \pm 0.1$ & 0.4 & $0.3 \pm 0.1$ & 0.5 \\
\hline Calcium $\left(\mathrm{mg} \cdot \mathrm{kg}^{-1} \cdot \mathrm{d}^{-1}\right)$ & $12.17 \pm 5.18$ & $14.43 \pm 5.21$ & 9.38 & $10.88 \pm 4.78$ & 10.80 \\
\hline Copper $\left(\mathrm{mg} \cdot \mathrm{kg}^{-1} \cdot \mathrm{d}^{-1}\right)$ & $0.01 \pm 0.01$ & $0.01 \pm 0.01$ & 0.02 & $0.02 \pm 0.01$ & 0.02 \\
\hline Folate $\left(\mu \mathrm{g} \cdot \mathrm{kg}^{-1} \cdot \mathrm{d}^{-1}\right)$ & $2.50 \pm 1.12$ & $3.08 \pm 1.19$ & 2.68 & $2.18 \pm 0.95$ & 3.08 \\
\hline lodine $\left(\mu \mathrm{g} \cdot \mathrm{kg}^{-1} \cdot \mathrm{d}^{-1}\right)$ & $1.44 \pm 0.91$ & $1.83 \pm 1.06$ & 1.88 & $1.22 \pm 0.74$ & 2.15 \\
\hline Iron $\left(\mathrm{mg} \cdot \mathrm{kg}^{-1} \cdot \mathrm{d}^{-1}\right)$ & $0.12 \pm 0.04$ & $0.15 \pm 0.04$ & 0.12 & $0.12 \pm 0.04$ & 0.23 \\
\hline Magnesium $\left(\mathrm{mg} \cdot \mathrm{kg}^{-1} \cdot \mathrm{d}^{-1}\right)$ & $2.90 \pm 1.07$ & $3.22 \pm 1.21$ & 4.02 & $2.72 \pm 0.96$ & 4.15 \\
\hline Niacin $\left(\mathrm{mg} \cdot \mathrm{kg}^{-1} \cdot \mathrm{d}^{-1}\right)$ & $0.41 \pm 0.15$ & $0.51 \pm 0.17$ & 0.22 & $0.36 \pm 0.09$ & 0.20 \\
\hline Phosphorus $\left(\mathrm{mg} \cdot \mathrm{kg}^{-1} \cdot \mathrm{d}^{-1}\right.$ ) & $14.54 \pm 5.18$ & $16.46 \pm 5.89$ & 7.37 & $13.45 \pm 4.48$ & 8.46 \\
\hline Potassium (mg $\left.\mathrm{kg}^{-1} \cdot \mathrm{d}^{-1}\right)$ & $34.74 \pm 11.86$ & $38.42 \pm 13.70$ & 46.91 & $32.63 \pm 10.35$ & 53.85 \\
\hline Riboflavin $\left(\mathrm{mg} \cdot \mathrm{kg}^{-1} \cdot \mathrm{d}^{-1}\right)$ & $0.02 \pm 0.01$ & $0.02 \pm 0.01$ & 0.02 & $0.01 \pm 0.01$ & 0.02 \\
\hline Selenium $\left(\mu \mathrm{g} \cdot \mathrm{kg}^{-1} \cdot \mathrm{d}^{-1}\right)$ & $0.57 \pm 0.29$ & $0.77 \pm 0.35$ & 1.00 & $0.46 \pm 0.18$ & 0.92 \\
\hline Sodium $\left(\mathrm{g} \cdot \mathrm{kg}^{-1} \cdot \mathrm{d}^{-1}\right)$ & $0.04 \pm 0.01$ & $0.04 \pm 0.01$ & 0.03 & $0.04 \pm 0.01$ & 0.04 \\
\hline Thiamin $\left(\mathrm{mg} \cdot \mathrm{kg}^{-1} \cdot \mathrm{d}^{-1}\right)$ & $0.02 \pm 0.01$ & $0.02 \pm 0.01$ & 0.01 & $0.02 \pm 0.01$ & 0.01 \\
\hline Vitamin $A\left(\mu g \cdot \mathrm{kg}^{-1} \cdot \mathrm{d}^{-1}\right)$ & $9.25 \pm 5.94$ & $11.34 \pm 5.12$ & 9.38 & $8.05 \pm 6.13$ & 9.23 \\
\hline Vitamin $B_{12}\left(\mu \mathrm{g} \cdot \mathrm{kg}^{-1} \cdot \mathrm{d}^{-1}\right)$ & $0.06 \pm 0.04$ & $0.08 \pm 0.04$ & 0.02 & $0.05 \pm 0.02$ & 0.02 \\
\hline Vitamin $B_{6}\left(\mathrm{mg} \cdot \mathrm{kg}^{-1} \cdot \mathrm{d}^{-1}\right)$ & $0.02 \pm 0.01$ & $0.03 \pm 0.02$ & 0.02 & $0.02 \pm 0.01$ & 0.02 \\
\hline Vitamin $C\left(\mathrm{mg} \cdot \mathrm{kg}^{-1} \cdot \mathrm{d}^{-1}\right)$ & $0.81 \pm 0.54$ & $0.89 \pm 0.62$ & 0.54 & $0.77 \pm 0.49$ & 0.62 \\
\hline Vitamin $D\left(\mu \mathrm{g} \cdot \mathrm{kg}^{-1} \cdot \mathrm{d}^{-1}\right)$ & $0.03 \pm 0.02$ & $0.03 \pm 0.02$ & 0.13 & $0.03 \pm 0.02$ & 0.15 \\
\hline $\operatorname{Zinc}\left(\mathrm{mg} \cdot \mathrm{kg}^{-1} \cdot \mathrm{d}^{-1}\right)$ & $0.10 \pm 0.03$ & $0.12 \pm 0.04$ & 0.13 & $0.10 \pm 0.03$ & 0.11 \\
\hline
\end{tabular}

Daily nutrient intakes of all participants with data separated for sex to establish relative differences. Data was compared to recommendations. Military dietary reference values (MDRVs) were used for energy, macro and micronutrient intake recommendations. Recommended relative intakes were calculated by dividing the recommended absolute intake by the average body mass for each sex. Data presented as mean \pm standard deviations. No statistically significant differences between sexes were observed.

$[32]=0.289, p=483, \mathrm{ES}=0.21)$, vitamin $\mathrm{B}_{12}(\mathrm{t}[42]=3.043$, $p=0.004, \mathrm{ES}=0.95)$, phosphorus $(\mathrm{t}[32]=1.913, p=0.063$, $\mathrm{ES}=0.58)$, potassium $(\mathrm{t}[32]=1.584, p=0.121, \mathrm{ES}=0.48)$, selenium ( $[19.791]=3.351, p=0.003, \mathrm{ES}=1.11$ ), sodium (t [32] $=0.733, p=0.468, \mathrm{ES}=0.00)$, zinc ( $[32]=0.2130$, $p=0.039, \mathrm{ES}=0.57)$, iodine $(\mathrm{t}[32]=2.228, p=0.031, \mathrm{ES}=$ $0.67)$, niacin $(\mathrm{t}[20.989]=3.249, p=0.004, \mathrm{ES}=1.10)$, folate $(\mathrm{t}[32]=2.756, p=0.009, \mathrm{ES}=0.70)$, vitamin $\mathrm{D}(\mathrm{Z}=-$ 1.786, 0.074, $\mathrm{ES}=0.00)$, vitamin $\mathrm{B}_{6}(\mathrm{Z}=-1.837, p=0.066$, $\mathrm{ES}=0.63)$, copper $(\mathrm{Z}=-0.266, \quad p=0.790, \quad \mathrm{ES}=-0.45)$, thiamine $(Z=-1.102, p=0.271, E S=0.00)$ or riboflavin $(Z$ $=-2.807, p=0.005, \mathrm{ES}=0.57$ ) (Table 2).

\section{Discussion}

The aim of this study was to quantify daily energy, macro and micronutrient intake of British Army recruits in Phase One training and to compare intakes between men and women. Our primary finding was that men and women under consumed daily energy intake by $\sim 1200$ and $\sim 800$ $\mathrm{kcal} \cdot \mathrm{d}^{-1}$, respectively when compared to MDRVs. The
MDRVs are based on measurements of daily energy expenditures via the doubly labelled water method in a similar cohort within this population whilst undertaking the same programme in British Army Phase One training [18]. The reported underconsumption of daily energy intake in this population observed in this study is typical of military populations and values estimated here are similar to other research [21, 23, 25-27]. The observed under consumption of total calories in this study, meant that recruits did not meet MDRV and RDAs for specific macro and micronutrients. Furthermore, due to a lower daily energy intake of women compared to men, and higher RDA for some micronutrients (i.e. iron), women are at greater risk of inadequate intakes when compared to guidelines and need to increase habitual iron intake by $\sim 53 \%$ to meet the RDA of $14.8 \mathrm{mg} \cdot \mathrm{d}^{-1}$ (Table 1 ).

Energy intake of men and women in this study was inadequate when compared to MDRVs (Table 1) and this may increase the incidence of reduced energy availability [33] which, in turn, may in increase the risk of injury $[5,14]$. 
Reduced chronic energy availability may lead to impaired physiological functions such as metabolic rate, protein synthesis, bone health, menstrual function and cardiovascular health [33]. Musculoskeletal injury risk (MSKi) may be increased during periods of reduced energy availability with concomitant reductions in skeletal muscle mass are observed due to reduced protein turnover [34, 35] Furthermore, skeletal muscle response to the training stimulus maybe downregulated during periods of reduced energy availability. For example, a daily energy surplus of $\sim 358$ $478 \mathrm{kcal} \cdot \mathrm{d}^{-1}$ is recommended to maximise muscle hypertrophy with resistance training [36]. Energy restriction has been shown to downregulate mTOR signalling activity and this is likely due to the inhibited protein translation and subsequently lower phosphorylation of protein kinase B (AKt), the mammalian target of rapamycin (mTOR), ribosomal protein S6 kinase (P70S6K) and ribosomal protein S6 (rps6) [37]. An energy deficit of $~ 40 \%$ upregulates mRNA of the skeletal muscle ubiquitin proteasome system (UPS) which regulates skeletal muscle proteolysis [38]. Our data demonstrates men and women consumed adequate energy to prevent an estimated deficit vs. the MDRVs of $\leq 40 \%$ and consumed $\sim 31 \%$ and $\sim 29 \%$ less than the MDRVs, respectively, which may still be considered as a considerable energy deficit. In relation to bone health, reduced energy availability reduces calcium absorption, bone turnover and bone mineral density [5], and thus, increases stress fracture risk [39] with women appearing to be more affected than men [40]. Furthermore, a reduced energy availability will increase the risk of inadequate supply of macro and micronutrients, which will likely impair physical performance and increase the risk of injury further [6].

Men and women both consumed less than the minimum recommended intake for $\mathrm{CHO}$ compared to MDRVs (Table 1-2). These results are similar to intakes of U.S. Army personnel, which found 70\% of personnel consumed less than $6 \mathrm{~g} \cdot \mathrm{kg}^{-1} \cdot \mathrm{d}^{-1}$ carbohydrate [27]. Given that participants undergoing Phase One training have energy expenditures between $\sim 3000$ to $\sim 4000$ $\mathrm{kcal} \cdot \mathrm{d}^{-1}[1]$ which is comparable to athletes in team sports [41] it may be appropriate to aim for similar $\mathrm{CHO}$ intakes per day $\left(5-7 \mathrm{~g} \cdot \mathrm{kg}^{-1} \cdot \mathrm{d}^{-1}\right)$ [42]. As such, British Army recruits may not be maintaining muscle glycogen stores to support training. Lower intakes of $\mathrm{CHO}$ during intensified training periods have been shown to reduce exercise performance and mood state in athletes [4] and contribute to immunosuppression [32]. Sub-optimal intakes of $\mathrm{CHO}$ during hard training periods in athletes, increases concentrations of cortisol whilst attenuating the secretion of immunoglobin-A (SlgA), and thus, increases the risk of contracting an upper respiratory tract infection [32, 43]. Taken together, $\mathrm{CHO}$ intakes below recommended intakes whilst undergoing military training may result in missed training days and possibly failure to complete training due to increased illness and injury risk. Future research should assess the effects of additional $\mathrm{CHO}$ intake on training outcomes, illness and injury incidence. Furthermore, research investigating the impact of nutrient timing in this population is also warranted given the influence this may have on recovery, tissue repair, muscle protein synthesis and psychological mood [44]. It has been shown that British Army officer cadets may under consume suboptimal levels of $\mathrm{CHO}$ and protein between mealtimes [45] but data in the recruit population is currently lacking.

Protein intakes in men and women were less than the MDRVs but were in-line with sport nutrition guidelines $\left(1.2-2.0 \mathrm{~g} \cdot \mathrm{kg}^{-1} \cdot \mathrm{d}^{-1}\right)$ [12] although women did have a lower relative intake than men (Table 2). To date, however, specific protein intakes are not recommended for British Army recruits. Intakes in the range of 1.2-2.0 $\mathrm{g} \cdot \mathrm{kg}^{-1} \cdot \mathrm{d}^{-1}$ are recommended in athletes to support metabolic adaptation, repair, remodelling, and for protein turnover [12]. Despite both sexes meeting this range in this study, it should be noted that intakes were at the lower end of this, and that true protein requirements may be at the upper limit of this range to meet training demands $\left(1.5-2.0 \mathrm{~g} \cdot \mathrm{kg}^{-1} \cdot \mathrm{d}^{-1}\right)$. In fact, evidence now suggests endurance athletes require more than the original recommended intake of $1.2-1.4 \mathrm{~g} \cdot \mathrm{kg}^{-1} \cdot \mathrm{d}^{-1}$ and instead should consume $1.6-1.8 \mathrm{~g} \cdot \mathrm{kg}^{-1} \cdot \mathrm{d}^{-1}$ on intense training days [46]. Given the arduous nature of military training and that military type exercise (i.e. load carriage) stimulates muscle protein synthesis more than endurance type exercise (i.e. running) [47], military personnel may require a daily protein intake of $\geq 1.5 \mathrm{~g} \cdot \mathrm{kg}^{-1}$ [8]. Furthermore, intakes of $>2.0 \mathrm{~g} \cdot \mathrm{kg}^{-1}$ during energy restriction may be needed to maximise the loss of fat-mass whilst also maintaining lean-tissue mass [13]. A protein intake higher than that observed in the current study has been shown to have physiological and performance benefits [48-50]. A protein intake of $3.0 \mathrm{~g} \cdot \mathrm{kg} \cdot{ }^{-1} \mathrm{~d}^{-1}$ resulted in a $30 \%$ possibility that the decrement in time trial performance pre-and-post the intervention was attenuated vs. a moderate protein intake $\left(1.5 \mathrm{~g} \cdot \mathrm{kg}^{-1} \cdot \mathrm{d}^{-1}\right)$ [49]. U.S. Marines who were supplemented daily with protein $(12 \mathrm{~g}$ protein, $9.6 \mathrm{~g} \mathrm{CHO}, 3.6 \mathrm{~g}$ fat) for 54 -days had $14 \%$ fewer visits to the medical centre compared to the placebo group $(0 \mathrm{~g}$ protein, $9.6 \mathrm{~g} \mathrm{CHO}, 3.6 \mathrm{~g}$ fat) and $40 \%$ less visits to the medical centre compared to the control group [48]. More recently, U.S. Army soldiers participating in Initial Entry Training who supplemented daily with whey protein $(77 \mathrm{~g}, 580 \mathrm{kcal})$ had a greater reduction of fat-mass $(-4.5 \mathrm{~kg}$, Cohen's $\mathrm{d}=-$ 0.67 vs. $-2.7 \mathrm{~kg}$, Cohen's $\mathrm{d}=-0.40$ ) compared to a group who supplemented daily with $\mathrm{CHO}(127 \mathrm{~g}, 580 \mathrm{kcal})$. The total daily protein intake was $2.8 \mathrm{~g} \cdot \mathrm{kg}^{-1} \cdot \mathrm{d}^{-1}$ in the protein 
group, which is far greater than both men and women in the current study (Table 2) [50]. An increased protein intake $>1.5 \mathrm{~g} \cdot \mathrm{kg}^{-1} \cdot \mathrm{d}^{-1}$ may also have psychological benefits. Endurance trained cyclists undergoing three weeks of highintensity training had a $97 \%$ chance that a higher protein intake $\left(3 \mathrm{~g}^{\mathrm{kg}} \mathrm{kg}^{-1} \cdot \mathrm{d}^{-1}\right)$ attenuated increased symptoms of stress compared to a moderate protein intake $\left(1.5 \mathrm{~g} \cdot \mathrm{kg}^{-1} \cdot \mathrm{d}^{-}\right.$ $\left.{ }^{1}\right)$ when participants were weight stable and when $\mathrm{CHO}$ intake was matched between conditions $\left(6 \mathrm{~g} \cdot \mathrm{kg}^{-1} \cdot \mathrm{d}^{-1}\right)$ [49]. This provides the rationale that protein intake should be considered in relation to other functions other than muscle protein synthesis and that a daily protein intake $>1.5 \mathrm{~g} \cdot \mathrm{kg}^{-1}$ may provide psychological benefits to individuals undergoing intense training (i.e. military training). Given the apparent benefits on increasing dietary protein to $>2.0 \mathrm{~g} \cdot \mathrm{kg}^{-1} \cdot \mathrm{d}^{-1}$ in periods of arduous training, it should be investigated if an additional protein intake to that of habitual intakes in British Army recruits in Phase One training influences training adaptions and training outcomes.

The total micronutrient intake data for the cohort showed that there was an inadequate intake of magnesium, vitamin $\mathrm{D}$, potassium, selenium, copper, iodine and folate (Table 1-2). Similarly, data collected in men and women during Basic Combat Training in the U.S. Army showed an inadequate intake of vitamin D, magnesium and potassium with women under consuming calcium and iron [10]. Given the reported intake of calcium $\left(699 \pm 287 \mathrm{mg} \cdot \mathrm{d}^{-1}\right)$ and iron $\left(7 \pm 2 \mathrm{mg} \cdot \mathrm{d}^{-1}\right)$ in women in this study, the risk of an inadequate intake of these micronutrients in this population is highlighted. Previously, it has been observed that training increase bone mineral content (BMC) and bone mineral density (BMD) of the arms, legs and pelvis in men and women undergoing the same training course at ATC(P). Conversely, it was observed training reduced $\mathrm{BMC}$ for the trunk and ribs and BMD for the ribs in both men and women (unpublished observations). These changes in BMD and BMC may be explained by habitual calcium intakes $\left(837 \pm 383 \mathrm{mg} \cdot \mathrm{d}^{-1}\right)$ with some consuming less than the RDA as shown by the reported standard deviation. Furthermore, it has previously been reported that only $9 \%$ of men and $36 \%$ of women entering Phase one training are vitamin D sufficient [51]. Given the inadequate intake of vitamin D and calcium, it should be investigated if increasing the intake of these micronutrients benefits training outcomes. For instance, female U.S. Navy recruits undergoing basic training who supplemented daily with $2000 \mathrm{mg}$ calcium and $800 \mathrm{IU}$ vitamin D had a $21 \%$ reduction in stress fracture incidence compared to a control group [52]. It is unknown, however, if the reduction was due to an increased calcium or vitamin D intake. The low habitual intake of iron in women compared to the RDA (Table 1-2) is comparable to that of their U.S.
Army counterparts [10]. British Army training appears to have a deleterious effect on iron status with ferritin and haemoglobin decreasing significantly pre and post Phase One training in men and women. Ferritin has been shown to reduce from 105.1 to $78.7 \mu \mathrm{g} \cdot \mathrm{L}^{-1}$ in men and from 52.7 to $47.7 \mu \mathrm{g} \cdot \mathrm{L}^{-1}$ in women. Haemoglobin has been shown to reduce from 149.7 to $147.1 \mathrm{~g} \cdot \mathrm{dL}^{-1}$ in men and from 139.2 to $132.1 \mathrm{~g} \cdot \mathrm{dL}^{-1}$ in women in 14 weeks of training. These changes in iron status contributed to a 6.9 and 2.3\% development of anaemia in women and men, respectively [53]. As such, research investigating iron requirements and the potential benefits of iron supplementation in British Army recruits undergoing Phase One training may be warranted. It is possible that recruits may require $70 \%$ more than the RDA [12]. For example, similar to athletes, British Army recruits who engage in regular exercise increase hepcidin levels which then inhibits iron absorption and contributes to a decrease in iron status [54]. Therefore an intervention may be to increase dietary iron intake particularly during periods not in close proximity to exercise to promote iron absorption and thus iron status [12].

\section{Conclusion}

Energy intake in men and women in British Army Phase One training is inadequate when compared to MDRVs. When considered to MDRVs, men and women both under consume $\mathrm{CHO}$ and protein and therefore interventions to combat this should be considered. Given this and the potential benefits of increasing protein intakes above 1.5 $\mathrm{g} \cdot \mathrm{kg}^{-1} \cdot \mathrm{d}^{-1}$ in military populations, future research investigating this should be explored. Furthermore, research aiming to better understand habitual protein requirements may be warranted. Given the low vitamin D intakes in both sexes and low iron and calcium intakes in women, research investigating the effects of micronutrient supplementation on training outcomes is needed. Finally, research which investigates changes in habitual dietary intake during Phase One training should be considered as well as data on the timing of daily energy and macronutrients intakes due to the potential effects on training adaptations and the implications of nutritional based interventions.

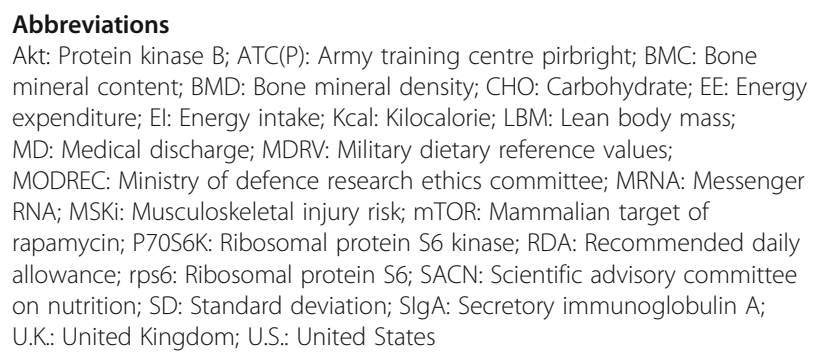

\section{Acknowledgements}

The authors would like to acknowledge Miss Louise Corfield, Miss Bethan Moriarty, Mr. Luke Davies and Mr. Alfie Gordon for their assistance with 
participant recruitment and data collection. As well as the training staff and recruits who volunteered to take part.

\section{Authors' contributions}

SC and RI designed the study. SC and AR recruited participants and conducted data collection. SC and AR undertook analysis of all data. SC, JR and LS interpreted the data. SC wrote the paper. All authors reviewed and approved the final manuscript.

\section{Funding}

This study was funding by the Army Recruiting and Initial Training Command, U.K. Ministry of Defence.

\section{Availability of data and materials}

Datasets used and/or analysed during the study are available from the corresponding author in reasonable request.

\section{Ethics approval and consent to participate}

This study was conducted in accordance with the declaration of Helsinki and was approved by the United Kingdom Ministry of Defence Ethics Committee (843/MODREC/18). Written informed consent was provided by all individual participants in this study.

\section{Consent for publication}

Not applicable

\section{Competing interests}

There are no competing interests from the authors.

\section{Received: 30 August 2019 Accepted: 26 November 2019}

Published online: 10 December 2019

\section{References}

1. O'Leary TJ, Saunders SC, McGuire SJ, Venables MC, Izard RM. Sex differences in training loads during British Army basic training. Med Sci Sport Ex. 2018 Dec;50(12):2565-74.

2. Blacker SD, Wilkinson DM, Bilzon JLJ, Rayson MP. Risk factors for training injuries among British Army recruits. Mil Med. 2008 Mar;173(3):278-86.

3. Richmond VL, Carter JM, Wilkinson DM, Horner FE, Rayson MP, Wright A, et al. Comparison of the physical demands of single-sex training for male and female recruits in the British Army. Mil Med. 2012 Jun;177(6):709-15.

4. Achten J, Halson SL, Moseley L, Rayson MP, Casey A, Jeukendrup AE. Higher dietary carbohydrate content during intensified running training results in better maintenance of performance and mood state. J App Phys. 2004 Apr; 96(4):1331-40

5. Close GL, Sale C, Baar K, Bermon S. Nutrition for the prevention and treatment of injuries in track and field athletes. Int J Sport Nut Ex Met. 2019 Jan;24:1-26.

6. Moran DS, Heled Y, Arbel Y, Israeli E, Finestone AS, Evans RK, et al. Dietary intake and stress fractures among elite male combat recruits. J Intern Soc Sport Nut. 2012;9:1-7.

7. Wardle SL, Greeves JP. Mitigating the risk of musculoskeletal injury: a systematic review of the most effective injury prevention strategies for military personnel. J Sci Med Sport. 2017;20:S3-10.

8. Pasiakos SM, Austin KG, Lieberman HR, Askew EW. Efficacy and safety of protein supplements for U.S. armed forces personnel: consensus statement. J Nutr. 2013 Nov 1;143(11):1811S-4S.

9. O'Leary TJ, Saunders SC, McGuire SJ, Izard RM. Sex differences in neuromuscular fatigability in response to load carriage in the field in British Army recruits. J Sci Med Sport. 2018;21(6):591-5.

10. Lutz LJ, Gaffney-Stomberg E, Karl JP, Hughes JM, Guerriere Kl, McClung JP. Dietary intake in relation to military dietary reference values during Army basic combat training; a multi-center. Cross-sectional Study Mil Med. 2019. 184(3-4):E223-30

11. Kerksick CM, Wilborn CD, Roberts MD, Smith-Ryan A, Kleiner SM, Jäger R, et al. ISSN exercise \& sports nutrition review update: research \& recommendations. J Intern Soc Sport Nut. 2018 Dec 1;15(1):38.

12. Thomas DT, Erdman KA, Burke LM. Position of the academy of nutrition and dietetics, dietitians of Canada, and the American College of Sports Medicine: nutrition and athletic performance. J Acad Nut Diet. 2016 Mar 1; 116(3):501-28.
13. Jäger R, Kerksick CM, Campbell Bl, Cribb PJ, Wells SD, Skwiat TM, et al. International Society of Sports Nutrition Position Stand: protein and exercise. J Intern Soc Sport Nut. 2017;14:20.

14. Ihle R, Loucks AB. Dose-response relationships between energy availability and bone turnover in young exercising women. J Bone Min Res. 2004;19(8): 1231-40.

15. Zanker CL, Swaine IL. Responses of bone turnover markers to repeated endurance running in humans under conditions of energy balance or energy restriction. Euro J App Phys. 2000;83(4-5):434-40.

16. Li P, Yin Y, Li D, Kim SW, Wu G. Review article amino acids and immune function. Brit J Nut. 2007:98(2):237-52.

17. Green MW, Rogers PJ, Elliman NA, Gatenby SJ. Impairment of cognitive performance associated with dieting and high levels of dietary restraint. Phys Beh. 1994;55(3):447-52.

18. SACN Statement on Military Dietary Reference Values for Energy. 50. https:// www.gov.uk/government/publications/sacn-statement-on-military-dietaryreference-values-for-energy. Accessed 11 Nov 2019.

19. VanHeest JL, Rodgers CD, Mahoney CE, De Souza MJ. Ovarian suppression impairs sport performance in junior elite female swimmers. Med Sci Sport Ex. 2014 Jan;46(1):156-66.

20. O'Leary TJ, Gifford RM, Double RL, Reynolds RM, Woods DR, Wardle SL, et al. Skeletal responses to an all-female unassisted Antarctic traverse. Bone. 2019 Apr;121:267-76.

21. McClung HL, Champagne CM, Allen HR, McGraw SM, Young AJ, Montain SJ, et al. Digital food photography technology improves efficiency and feasibility of dietary intake assessments in large populations eating ad libitum in collective dining facilities. App. 2017;116:389-94.

22. Israeli E, Merkel D, Constantini N, Yanovich R, Evans RK, Shahar D, et al. Iron deficiency and the role of nutrition among female military recruits. Med Sci Sport Ex. 2008:40:S685-90.

23. Ramsey CB, Hostetler C, Andrews A. Evaluating the nutrition intake of U.S. military service members in garrison. Mil Med. 2013;178(12):1285-90.

24. Etzion-Daniel Y, Constanini N, Finestone AS, Shahar DR, Israeli E, Yanovich R, et al. Nutrition consumption of female combat recruits in Army basic training. Med Sci Sport Ex. 2008;40:S677-84.

25. Stark AH, Weis N, Chapnik L, Barenboim E, Reifen R. Dietary intake of pilots in the Israeli air force. Mil Med. 2015;173(8):780-4.

26. Beals K, Darnell ME, Lovalekar M, Baker RA, Nagai T, San-Adams T, et al. Suboptimal nutritional characteristics in male and female soldiers compared to sports nutrition guidelines. Mil Med. 2015;180(12):1239-46.

27. McAdam J, McGinnis K, Ory R, Young K, Frugé AD, Roberts M, et al. Estimation of energy balance and training volume during Army initial entry training. J Intern Soc Sport Nut. 2018;15(1):55.

28. Aguilar-Farias N, Peeters GMEE. (Geeske), Brychta RJ, Chen KY, Brown WJ. Comparing ActiGraph equations for estimating energy expenditure in older adults. J Sports Sci. 2019 Jan;37(2):188-95.

29. Magkos F, Yannakoulia M. Methodology of dietary assessment in athletes: concepts and pitfalls. Curr Op Clin Nut Met Care. 2003;6(5):539-49.

30. Ahmed M, Mandic I, Lou W, Goodman L, Jacobs I, L'Abbé MR. Validation of a tablet application for assessing dietary intakes compared with the measured food intake/food waste method in military personnel consuming field rations. Nutrients. 2017 Mar;9(3):200.

31. Braakhuis AJ, Meredith K, Cox GR, Hopkins WG, Burke LM. Variability in estimation of self-reported dietary intake data from elite athletes resulting from coding by different sports dietitians. Intern J Sport Nut Ex Met. 2003 Jun;13(2):152-65.

32. Costa RJS, Jones GE, Lamb KL, Coleman R, Williams JHH. The effects of a high carbohydrate diet on cortisol and salivary immunoglobulin a (s-lgA) during a period of increase exercise workload amongst Olympic and ironman triathletes. Int J Sport Med. 2005 Apr;26(10):880-5.

33. Mountjoy M, Sundgot-Borgen J, Burke L, Carter S, Constantini N, Lebrun C, et al. The IOC consensus statement: beyond the female athlete triad-relative energy deficiency in sport (RED-S). Brit J Sport Med. 2014;48(7):491-7.

34. Carbone JW, McClung JP, Pasiakos SM. Skeletal muscle responses to negative energy balance: effects of dietary protein. Ad Nut. 2012;3(2):119-26.

35. Pasiakos SM, Margolis LM, Orr JS. Optimized dietary strategies to protect skeletal muscle mass during periods of unavoidable energy deficit. FASEB J: Official Publication Fed Am Soc Exp Biol. 2015:29(4):1136-42.

36. Slater GJ, Dieter BP, Marsh DJ, Helms ER, Shaw G, Iraki J. Is an Energy Surplus Required to Maximize Skeletal Muscle Hypertrophy Associated With Resistance Training. Front Nutr. 2019;6:131. 
37. Margolis LM, Murphy NE, Martini S, Gundersen Y, Castellani JW, Karl JP, et al. Effects of supplemental energy on protein balance during 4-d Arctic military training. Med Sci Sport Ex. 2016 Aug;48(8):1604-12.

38. Carbone JW, Margolis LM, McClung JP, Cao JJ, Murphy NE, Sauter ER, et al. Effects of energy deficit, dietary protein, and feeding on intracellular regulators of skeletal muscle proteolysis. FASEB J. 2013 Dec;27(12):5104-11.

39. Ackerman KE, Sokoloff NC, De Nardo MG, Clarke HM, Lee H, Misra M. Fractures in relation to menstrual status and bone parameters in young athletes. Med Sci Sport Ex. 2015;47(8):1577-86.

40. Papageorgiou M, Elliott-Sale KJ, Parsons A, Tang JCY, Greeves JP, Fraser WD, et al. Effects of reduced energy availability on bone metabolism in women and men. Bone. 2017 Dec;105:191-9.

41. Brinkmans NYJ, ledema N, Plasqui G, Wouters L, Saris WHM, van Loon LC, et al. Energy expenditure and dietary intake in professional football players in the Dutch premier league: implications for nutritional counselling. J Sport Sci. 2019 Feb;16:1-9.

42. Burke LM, Hawley JA, Wong SHS, Jeukendrup AE. Carbohydrates for training and competition. J Sport Sci. 2011 Jan 1;29:S17-27.

43. Gleeson M, Nieman DC, Pedersen BK. Exercise, nutrition and immune function. J Sports Sci. 2004 Jan;22(1):115-25.

44. Kerksick C, Harvey T, Stout J, Campbell B, Wilborn C, Kreider R, et al. International Society of Sports Nutrition position stand: nutrient timing. J Int Soc Sports Nutr. 2008 Dec;5(1):17.

45. Edwards VC, Myers SD, Siddall AG, Thompson JES, Powell SD, Jackson S, et al. Timing of energy and macronutrient intake of British Army officer cadets during military training. Med Sci Sport Ex. 2018 May:50:639.

46. Kato H, Suzuki K, Bannai M, Moore DR. Protein Requirements Are Elevated in Endurance Athletes after Exercise as Determined by the Indicator Amino Acid Oxidation Method. Fisher G, editor. PLoS ONE. 2016 Jun 20;11(6)

47. Pasiakos SM, McClung HL, Margolis LM, Murphy NE, Lin GG, Hydren JR, et al. Human Muscle Protein Synthetic Responses during Weight-Bearing and Non-Weight-Bearing Exercise: A Comparative Study of Exercise Modes and Recovery Nutrition. PLoS One. 2015;10(10).

48. Flakoll PJ, Judy T, Flinn K, Carr C, Flinn S. Postexercise protein supplementation improves health and muscle soreness during basic military training in marine recruits. J App Phys. 2004 Mar:96(3):951-6.

49. Witard OC, Jackman SR, Kies AK, Jeukendrup AE, Tipton KD. Effect of increased dietary protein on tolerance to intensified training. Med Sci Sports Ex. 2011 Apr;43(4):598-607.

50. McAdam J, McGinnis K, Beck D, Haun C, Romero M, Mumford P, et al. Effect of whey protein supplementation on physical performance and body composition in Army initial entry training soldiers. Nutrients. 2018 Sep 6;10(9):1248.

51. Carswell AT, Oliver SJ, Wentz LM, Kashi DS, Roberts R, Tang JCY, et al. Influence of vitamin D supplementation by sunlight or Oral D3 on exercise performance. Med Sci Sports Ex. 2018 Dec:50(12):2555-64.

52. Lappe J, Cullen D, Haynatzki G, Recker R, Ahlf R, Thompson K. Calcium and vitamin $D$ supplementation decreases incidence of stress fractures in female navy recruits. J Bone Min Res. 2008;23(5):741-9.

53. Jackson S, Walsh N, Oliver S, Izard R, Tang J, Fraser W, et al. Changes in iron status of British Army recruits in basic military training. J Sci Med Sport. 2017 Nov 1;20:S164

54. Pasiakos SM, Margolis LM, Murphy NE, McClung HL, Martini S, Gundersen Y, et al. Effects of exercise mode, energy, and macronutrient interventions on inflammation during military training. Physiol Rep. 2016 Jun;7:4(11).

\section{Publisher's Note}

Springer Nature remains neutral with regard to jurisdictional claims in published maps and institutional affiliations.

Ready to submit your research? Choose BMC and benefit from:

- fast, convenient online submission

- thorough peer review by experienced researchers in your field

- rapid publication on acceptance

- support for research data, including large and complex data types

- gold Open Access which fosters wider collaboration and increased citations

- maximum visibility for your research: over $100 \mathrm{M}$ website views per year

At $\mathrm{BMC}$, research is always in progress.

Learn more biomedcentral.com/submissions 